\title{
Wilderness cold-exposure injuries: An African perspective
}

\author{
R Hofmeyr, DipPEC, DA, MMed (Anaes), FCA, FAWM \\ Department of Anaesthesia and Perioperative Medicine, Faculty of Health Sciences, University of Cape Town; and WildMedix, Cape Town, \\ South Africa
}

Corresponding author: R Hofmeyr (ross.hofmeyr@uct.ac.za)

\begin{abstract}
Cold injuries may be systemic (hypothermia) or local (frostbite or non-freezing cold injury). Hypothermia (core temperature of $<35^{\circ} \mathrm{C}$ ) is very common in South Africa, particularly in trauma patients, and conditions suitable for the development of local cold injuries frequently occur. Despite this, cold injuries are underdiagnosed, and many practitioners lack insight into the modern management of frostbite. Risk factors include low ambient temperatures, increased duration of exposure, trauma, immobility, intoxication or mental illness, lack of protective clothing or equipment, immersion, level of fitness, extremes of age, and ethnicity. Core temperature measurement should be obtained using an oesophageal probe in intubated patients, or a rectal thermometer in those who are conscious. Field management involves prevention of further heat loss by insulation and vapour barriers, and moving the patient to shelter. Rewarming strategies depend on the severity of hypothermia, and include core rewarming with heat packs, warm blankets and warm fluids (orally or intravenously). Unconscious victims of severe hypothermia require careful handling, advanced airway management and invasive rewarming, which may include extracorporeal means. Local cold injuries should be protected and rewarmed in a warm-water bath as soon as they are no longer at a risk of refreezing. Warming should be completed before grading and prognostication. Surgery should be deferred in almost all cases. Intra-arterial thrombolysis and prostacyclin-analogue infusions are novel therapies which may prevent tissue loss.
\end{abstract}

S Afr Med J 2017;107(7):566-570. DOI:10.7196/SAMJ.2017.v107i7.12610

\section{Scenario}

As a much-needed break from clinical duties, you have taken your family on a winter week away to a mountain cabin in the Drakensberg. From your chair next to the fire you are watching the snow fall, but are interrupted by a loud knock. A member of another group has not returned from his solo morning walk to the nearby waterfall, and his friends have found him on the trail with a badly sprained ankle from a slip on icy rocks. They are looking for help to carry him back to the cabin, so you readily volunteer. On arrival you find that he is unable to stand unaided, feels very cold and is barely coherent. He complains that he is unable to feel either of his feet. You realise that he is in quite serious danger; mountain rescuers are at least an hour away, and no helicopter can fly through the freshly falling snow. Quickly, you begin to formulate a plan.

\section{Background}

South Africa (SA) immediately conjures images of sun, heat, dry deserts and lush jungle, but any Karoo farmer or resident of the highveld will attest to the severity of chill winter nights. Our mountainous regions and the high interior of the country enjoy frequent snowfall, and winter temperatures routinely reach subzero at night. Indeed, the coldest recorded temperature in SA (measured by the SA Weather Service at Buffelsfontein near Molteno in the Eastern Cape Province in June 1996) was $-18.6^{\circ} \mathrm{C} .{ }^{[1]}$ However, freezing temperatures are not required to place both healthy individuals and ill or injured patients at risk of cold injury. Systemic cold injury - hypothermia is dichotomously extremely common and highly underdiagnosed in traumatic injury victims, and is not uncommon even in hospitalised patients presenting for surgery or intensive care. ${ }^{[2-7]}$

Local cold injuries such as frostbite are rarely considered in SA, but as described above, suitable conditions definitely exist, and accidental cases within our borders have been described. ${ }^{\left[{ }^{[8]}\right.}$ Further cases are contributed through Cape Town's role as one of the international gateways to Antarctica, with several medical repatriations occur- ring each season, and local occupational causes (such as individuals working with coolants and refrigeration processes). Furthermore, inadequate attention has been given to the entity of non-freezing cold injury (NFCI), which is possibly underrecognised and underdiagnosed in specific populations such as manual and construction workers, and commercial fishermen in frigid conditions. Because of the relative scarcity of these cases, SA clinicians are typically not well versed in their management. Specialists in fields such as trauma, and vascular and plastic surgery may not be familiar with the differences in injury progression and management from other causes of tissue ischaemia and necrosis, such as chronic peripheral vascular disease.

This brief review aims to provide the African practitioner with an overview and understanding of the issues surrounding diagnosis and management of systemic and local cold injuries in our context.

\section{Systemic cold injury: Hypothermia Definition}

Normal core body temperature is subject to tight homeostatic control of less than half a degree around a set point of $\sim 37^{\circ} \mathrm{C}$. This varies between individuals, and shows both gender and diurnal variation. Hypothermia is traditionally defined as a core temperature of $<35^{\circ} \mathrm{C} .{ }^{[9]}$ (While this definition is widely accepted in the literature, it is worth noting that the peri-operative literature considers a temperature of $<36^{\circ} \mathrm{C}$ to be peri-operative hypothermia, as this has been associated with increased complications.) Any individual presenting with a temperature of $<35^{\circ} \mathrm{C}$ should therefore be considered hypothermic and warmed to a target of $36-37^{\circ} \mathrm{C}$.

\section{Risk factors}

Hypothermia risk is closely related to ambient temperature and duration of exposure, but is also influenced by the level of fitness and physical activity, body habits, age, experience, protective clothing and equipment, presence of immersion in water or soaking of clothes of the victim. Ethnicity is relevant in Africa, and does play a role: in 
groups with equal exposure, those of African ethnic heritage have been shown to be at greater risk than Caucasians. ${ }^{[10-12]}$ There is also a strong association between mental illness, alcohol and drug intoxication and hypothermia risk. However, cold injuries are completely preventable through education, appropriate clothing and equipment, and good decision-making in the wilderness (Fig. 1). Interventions to reduce the burden of disease should focus on these strategies.

\section{Wilderness hypothermia guidelines}

Multiple guidelines on the management of hypothermia exist. ${ }^{[13-15]}$ In the wilderness setting, those published by the Wilderness Medical Society and International Commission on Alpine Rescue are particularly useful, with relevant modification for the SA context. A brief overview is provided below.

Accidental hypothermia in the wilderness setting has been classified by numerous means, including symptoms and clinical signs, and measured core temperature (Table 1). Field diagnosis and progression of hypothermia can be assisted by the aide mémoire of the 'umbles': the patient grumbles, fumbles, stumbles, mumbles and finally crumbles. ${ }^{[16]}$ This reflects the change in personality as individuals begin to feel cold, the progressive loss of first fine and then gross motor co-ordination, the late descent into incoherence, and final collapse. Additional signs are the onset and later loss of shivering, pallor and inappropriate behaviour.

Core temperature measurement is critical in managing hypothermia. However, this presents several problems and misconceptions. The gold standard of core temperature determination is direct measurement in the pulmonary artery using a thermistor-tipped pulmonary artery catheter. Outside of the research setting, this is practically impossible in the field, and is rare even in clinical practice in the emergency department. Using a mid-oesophageal thermistor is considered of equal accuracy, with response times to changes in temperature nearly as swift as pulmonary artery measurement. Although

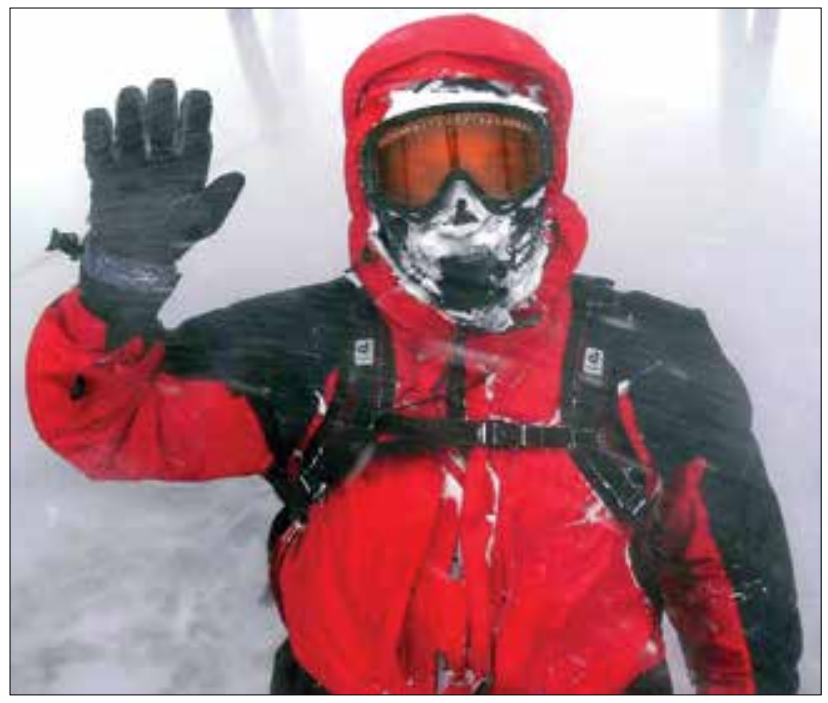

Fig. 1. A well-equipped individual in harsh environmental conditions. Care has been taken to prevent skin exposure to high winds through the use of goggles, a face mask and gloves. Insulation is worn under a windproof outer layer to reduce conductive, convective and evaporative heat loss.

Table 1. Comparison of Wilderness Medical Society staging and Swiss hypothermia classification with clinical signs and management recommendations

\begin{tabular}{|c|c|c|c|c|}
\hline Core temperature & Clinical signs & $\begin{array}{l}\text { Wilderness Medical } \\
\text { Society guidelines }^{[9]}\end{array}$ & $\begin{array}{l}\text { Swiss hypothermia } \\
\text { grading }^{[13]}\end{array}$ & Management recommendations \\
\hline$>36^{\circ} \mathrm{C}$ & Normal & Normal & Normal & \multirow{2}{*}{$\begin{array}{l}\text { Reduce heat loss by shelter } \\
\text { or clothing; increase heat } \\
\text { production with exercise or fooc }\end{array}$} \\
\hline$>35^{\circ} \mathrm{C}$ & Feeling cold & $\begin{array}{l}\text { Cold stressed, not } \\
\text { hypothermic }\end{array}$ & $\begin{array}{l}\text { Cold stressed, not } \\
\text { hypothermic }\end{array}$ & \\
\hline $35^{\circ} \mathrm{C}$ & Shivering commences & \multirow{4}{*}{$\begin{array}{l}\text { Mild HT } \\
\left(32-35^{\circ} \mathrm{C}\right)\end{array}$} & \multirow{4}{*}{$\begin{array}{l}\text { HT I: clear consciousness } \\
\text { with shivering }\end{array}$} & \multirow{4}{*}{$\begin{array}{l}\text { Prevent further loss; measure } \\
\text { core temperature; encourage } \\
\text { passive warming by caloric } \\
\text { replacement; warm actively if } \\
\text { possible }\end{array}$} \\
\hline $34^{\circ} \mathrm{C}$ & $\begin{array}{l}\text { Loss of fine motor } \\
\text { co-ordination }\end{array}$ & & & \\
\hline $33^{\circ} \mathrm{C}$ & $\begin{array}{l}\text { Behaviour changes, } \\
\text { dysarthria }\end{array}$ & & & \\
\hline $32^{\circ} \mathrm{C}$ & Lethargy & & & \\
\hline $31^{\circ} \mathrm{C}$ & \multirow{2}{*}{$\begin{array}{l}\text { Ataxia and impaired } \\
\text { consciousness }\end{array}$} & \multirow{4}{*}{$\begin{array}{l}\text { Moderate HT } \\
\left(28-32^{\circ} \mathrm{C}\right)\end{array}$} & \multirow{4}{*}{$\begin{array}{l}\text { HT II: impaired conscious- } \\
\text { ness with shivering }\end{array}$} & \multirow{4}{*}{$\begin{array}{l}\text { As above, plus active warming } \\
\text { in all cases: warm fluids, heat } \\
\text { packs, forced air warmers; } \\
\text { intravenous or intraosseous } \\
\text { access, protection from trauma, } \\
\text { afterdrop and shocks }\end{array}$} \\
\hline $30^{\circ} \mathrm{C}$ & & & & \\
\hline $29^{\circ} \mathrm{C}$ & Shivering stops & & & \\
\hline $28^{\circ} \mathrm{C}$ & $\begin{array}{l}\text { Decreased fibrillation } \\
\text { threshold }\end{array}$ & & & \\
\hline $27^{\circ} \mathrm{C}$ & \multirow[t]{2}{*}{ Loss of consciousness } & \multirow{6}{*}{$\begin{array}{l}\text { Severe HT } \\
\left(<28^{\circ} \mathrm{C}\right) \\
\text { Profound HT } \\
\left(<24^{\circ} \mathrm{C} \text { or }<20^{\circ} \mathrm{C}\right)\end{array}$} & \multirow[t]{4}{*}{ HT III: unconscious } & \multirow{6}{*}{$\begin{array}{l}\text { As above, plus protect airway } \\
\text { ( } \mathrm{SGA} \text { or careful intubation); } \\
\text { supplemental } \mathrm{O}_{2} \text {; ventilation; } \\
\text { oesophageal temperature probe; } \\
\mathrm{CPR} \text { if no signs of life; warm } \\
\text { invasively and aggressively; } \\
\text { terminate if serum potassium } \\
>12 \mathrm{mmol} / \mathrm{L} \text { or injuries } \\
\text { incompatible with life }\end{array}$} \\
\hline $26^{\circ} \mathrm{C}$ & & & & \\
\hline $25^{\circ} \mathrm{C}$ & \multirow{2}{*}{$\begin{array}{l}\text { Loss of reflexes and pain } \\
\text { response }\end{array}$} & & & \\
\hline $24^{\circ} \mathrm{C}$ & & & & \\
\hline$<24^{\circ} \mathrm{C}$ & $\begin{array}{l}\text { Hypotension and } \\
\text { bradycardia }\end{array}$ & & HT IV: apparent death & \\
\hline$<13^{\circ} \mathrm{C}$ & $\begin{array}{l}\text { Undetectable vital signs; } \\
\text { asystole likely below } 18^{\circ} \mathrm{C}\end{array}$ & & $\begin{array}{l}\text { HT V: irreversible } \\
\text { hypothermic death }\end{array}$ & \\
\hline
\end{tabular}


feasible in the field, it typically requires an unconscious or sedated patient who has an advanced airway device in place. However, many modern monitoring devices (including those used in prehospital medicine, the emergency department and the operating theatre) can be used for this propose. Rectal temperature measurement using either a thermistor or thermometer is accurate and accessible, but slower to respond to rapid temperature changes. A low-reading thermometer that is inserted to $15 \mathrm{~cm}$ beyond the anal sphincter is ideal. Barriers to use include social acceptability, and the need to remove clothing if in the field, thereby exposing the patient to further cold insult. Oral measurement is also suboptimal: it is greatly affected by respiration and fluid intake, and is therefore of little use if warming is being undertaken by administration of hot fluids. However, oral temperature measurement can be useful to rule out hypothermia if $>35^{\circ} \mathrm{C}$ before taking warm fluids. Axillary and skin temperatures are unreliable in patients with hypothermia. True tympanic membrane measurement reflects central compartment blood temperature by direct perfusion via the carotid artery, but requires an epitympanic contact thermistor, which is rarely available in the field and influenced by ambient temperature if incorrectly placed and not insulated. Infrared tympanic thermometers, despite their convenience, have consistently been shown to be unreliable. ${ }^{[17]}$

\section{Field management}

Once the safety of rescuers has been confirmed, the first priority in field management of hypothermia is prevention of further heat loss through the use of insulation and vapour barriers. Any dry item that traps air (clothing, blankets, sleeping bags or even bubble wrap) can be used for insulation. A vapour barrier is a layer impermeable to water vapour (and wind), which dramatically reduces convective and evaporative heat loss. Although specific products such as survival bags exist for this purpose, in low-resource settings even simple plastic refuse bags are effective.

In mild hypothermia (conscious patients who can walk), preventing further heat loss, providing warm calorie-rich drinks and allowing the patient to increase endogenous heat production by shivering or continuing to exercise, can be sufficient to ensure rewarming. If the patient is not able to drink or ambulate, moderate to severe hypothermia must be presumed. Rapid peripheral warming or exercise may precipitate 'afterdrop', where redistribution of blood from the central circulation to the periphery results in rapid drop of core temperature. Cooling lengthens the refractive period of cardiomyocytes, which can result in ventricular fibrillation (VF) and complete circulatory collapse. Therefore, exercise in these patients should be avoided if possible. They should be carried to shelter, and have active core rewarming using items such as heat packs or warm-water bottles, warm carbohydrate-containing fluids, and warmed blankets. Deliberate warming of cold extremities should only occur once core temperature has normalised.

Unconscious victims of severe hypothermia may appear dead. However, in the absence of injuries incompatible with life, efforts at warming and resuscitation should be made, if possible. This includes advanced airway management, vascular access (intraosseous access may be easiest in very cold patients), warm intravenous fluids, core rewarming and cardiopulmonary resuscitation (CPR).

\section{Hospital management}

Core rewarming efforts should be continued when patients present to hospital. The patient should be admitted to a monitored bed, with electrocardiograph, saturation, blood pressure and temperature monitoring as a minimum. Forced-air warming devices are effective, but care must be taken that the patient is dry before their application.
Any wet or restrictive clothing must be removed. Intravenous access should be obtained, which may require intraosseous catheterisation with infusion fluids at $40-42^{\circ} \mathrm{C}$. Unconscious patients should have an advanced airway (endotracheal tube or supraglottic airway) and mechanical ventilation. In the absence of palpable pulses, production of end-tidal carbon dioxide or the use of point-of-care ultrasound to assess cardiac activity and output are very valuable. Patients with an organised cardiac rhythm but no discernible pulse should have ongoing warming and resuscitation with fluid. If VF is present, a single attempt at defibrillation can be made. If unsuccessful, the patient should be warmed to at least $30^{\circ} \mathrm{C}$ before further attempts are made. Hypothermic patients may have a decreased response to vasoactive agents. Invasive warming through bladder, and peritoneal or pleural lavage can be used in severe cases. Extracorporeal rewarming and support of perfusion are gaining international acceptance in centres that have this capability, and should strongly be considered where available, as discussed in 'Emerging therapies' below.

\section{Local cold injuries}

Local cold injuries can be subdivided into frostnip, frostbite and NFCI. Frostnip is the reversible freezing of only the most superficial layer of the epidermis without any underlying tissue injury, and resolving within 30 minutes. As it is rare at temperatures $>-10^{\circ} \mathrm{C}$ and only common at $<-25^{\circ} \mathrm{C}$, it is exceptionally rare in the African context.

Frostbite involves the freezing of skin and other tissues resulting in damage to the affected area, which may heal or result in permanent tissue loss. Typically, this requires ambient temperatures below that at which tissue freezes $\left(-0.55^{\circ} \mathrm{C}\right)$, although it can occur at higher temperatures in the presence of significant convective cooling (wind chill). The severity of injury is dependent on duration of exposure, ambient temperature, evaporative cooling or immersion, type of clothing and/or exposure protection, underlying conditions that affect perfusion (such as diabetes, smoking, Raynaud's phenomenon and other peripheral vascular diseases) and the presence of alcohol/ drug intoxication or mental illness. Of these factors, duration of exposure is the most critical.

The precise mechanism of injury is not fully understood, but involves direct injury from formation of intracellular and extracellular ice crystals, subsequent intracellular dehydration due to increased oncotic pressure, and reperfusion injury during tissue warming. Endothelial damage leads to tissue oedema and formation of microthrombi, which occlude capillaries and worsen tissue ischaemia. Repeated freeze-thaw cycles lead to the most severe injuries.

In early frostbite, the area involved feels cold and may be painful, progressing to paraesthesia and/or numbness. The skin is pale or mottled. Later, the area becomes white and waxy to touch, and may be clearly demarcated. The tissue is insensate and feels woody (Fig. 2). With rewarming, erythema, bruising and blisters may form. Clear fluid-filled blisters imply full-thickness involvement of the skin (often described as mild or second-degree frostbite), whereas haemorrhagic blisters demonstrate the subcutaneous tissue damage of severe (third-degree) frostbite, which more frequently leads to tissue damage (Fig. 3). Absence of blisters in the presence of dark mottled tissue after rewarming indicates profound frostbite, which often involves muscle, tendon or bone, and will likely result in significant tissue loss though mummification and necrosis (Table 2).

NFCI usually presents with unresolving numbness, often accompanied by pain or paraesthesia. Upon rewarming, the site (usually a foot) becomes hyperaemic and oedematous. There is not usually blistering or tissue loss; if present, the injury should be treated as frostbite. Unrelenting pain is common and should be managed 


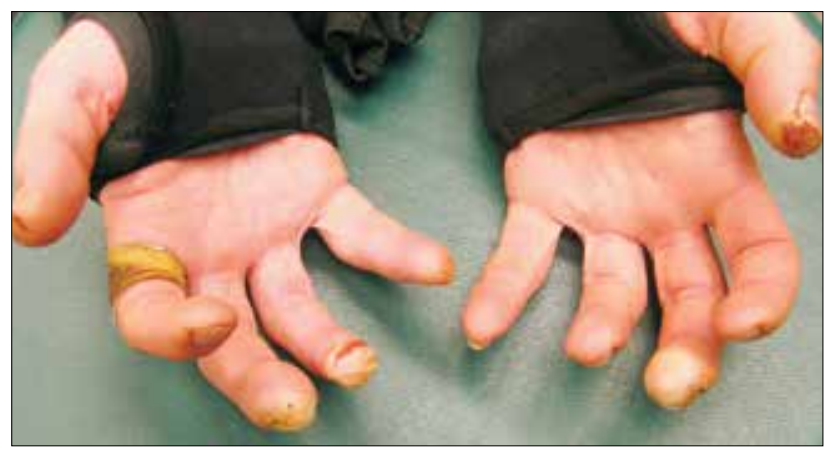

Fig. 2. Acute presentation of frostbite in a scientist at the SA Antarctic research station, superimposed on minor tissue loss from an earlier episode. Note the waxy white appearance of several fingertips, most easily seen on the third finger of the left hand. (Photo: author's collection.)

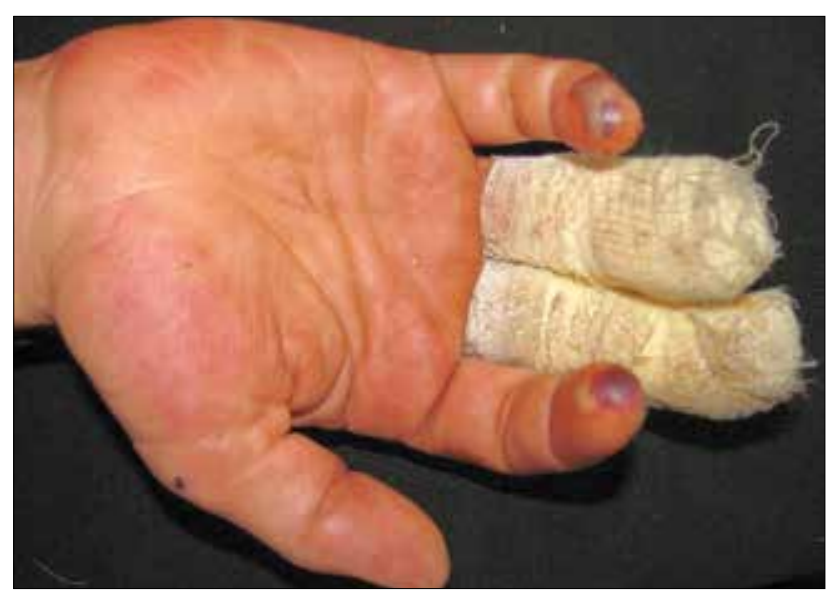

Fig. 3. Mixed frostbite lesions after thawing. Note hyperaemia (1st degree) of thenar area and presence of clear and haemorrhagic blisters (2nd and $3 \mathrm{rd}$ degree) on fingertips. Distal phalynx cyanosis (grade 2) hidden by protective dressings. (Photo: author's collection.)

aggressively. As it is neurogenic in origin, agents used for chronic pain management should be considered. In our setting, amitriptyline (25 mg initially) is an effective first-line agent.

Frostbite carries the prospect of significant morbidity, but is not an acute threat to life. However, in the wilderness it is almost always accompanied by a degree of hypothermia, and often with other traumatic injuries. The priority, therefore, is the immediate management of life-threatening conditions, including core rewarming if hypothermia is present. Indeed, aggressive peripheral warming in the presence of hypothermia may result in dangerous afterdrop in core temperature.

Because duration of exposure is the principal factor determining severity of frostbite, rapid rewarming of the frozen part is important. However, rewarming should not be attempted if it will impede removing the patient to a sheltered environment, or if refreezing may occur. For instance, a patient with frostbite of the feet may be able to walk to safety, but once rewarming has commenced would be unable to move unaided.

Rewarming is ideally performed in a water bath at $37-42^{\circ} \mathrm{C}$. In the field, the armpit or groin of a warm rescuer can be used. Care should be taken with the use of hot-water bottles, stoves or other heat sources, as the patient may be unable to feel the limb, or already be in sufficient pain that they cannot distinguish when burning of the tissue occurs. Rewarming is typically painful and analgesia should always be given. Aspirin (500 mg taken orally) may benefit rheology, and ibuprofen ( $800 \mathrm{mg}$ initially followed by $400 \mathrm{mg}$ 8-hourly) is useful for both analgesia and antiprostaglandin effects. Paracetamol, opiates and other modalities such as ketamine and methoxyflurane can be considered. Local or regional blocks with local anaesthetic provide good relief, and the resultant sympathectomy may be useful in improving perfusion, but this should be restricted to skilled hands and not used in NFCI, where it worsens the risk of chronic pain.

The affected part should be protected well with dry dressings. Blisters, if present, should not be deroofed. If very tense, some experts advise aspirating haemorrhagic blisters under strict aseptic conditions. If available in the field, simple prophylactic antibiotics can be given. Patients with any evidence of tissue damage/loss (grade 2 frostbite or higher) should always be evacuated to a suitable healthcare facility for assessment, as field diagnosis is poorly predictive of actual degree of tissue involvement.

On admission to hospital, patients with local cold injuries should be rapidly assessed to rule out hypothermia or other life-threatening insults. A targeted history, including duration of exposure, duration of freezing and time since rewarming, should be obtained. Any rings or jewellery must be removed. Prognostication or grading before thawing is not accurate and the affected areas should be rewarmed as soon as possible. The ideal method is by using a whirlpool bath at $37-42^{\circ} \mathrm{C}$. Where this is not available, a common foot spa bath or large basin with continuous stirring can be used. Care must be taken not to exceed this temperature. As mentioned previously, rewarming is usually very

\section{Table 2. Grading/classification of frostbite injuries}

\begin{tabular}{|c|c|c|}
\hline Traditional classification $^{[18]}$ & Modern grading ${ }^{[19]}$ & Tissue loss \\
\hline $\begin{array}{l}\text { 1st degree } \\
\text { Partial thick skin freezing; erythematous } \\
\text { or hyperaemic with minor oedema once thawed }\end{array}$ & $\begin{array}{l}\text { Grade } 1 \\
\text { No cyanosis visible on extremity } \\
\text { after thawing }\end{array}$ & None \\
\hline $\begin{array}{l}\text { 2nd degree } \\
\text { Full-thickness skin freezing; erythematous } \\
\text { with oedema; clear blisters once thawed }\end{array}$ & $\begin{array}{l}\text { Grade } 2 \\
\text { Cyanosis after thawing is restricted to } \\
\text { distal phalanx }\end{array}$ & $\begin{array}{l}\text { Rare/unlikely; limited to nails and soft } \\
\text { tissue }\end{array}$ \\
\hline $\begin{array}{l}\text { 3rd degree } \\
\text { Skin and subcutaneous tissue freezing; } \\
\text { cyanotic blue/black tissue with haemorr- } \\
\text { hagic blisters once thawed; may have necrosis }\end{array}$ & $\begin{array}{l}\text { Grade } 3 \\
\text { Cyanosis after thawing extends } \\
\text { to intermediate and proximal phalanx }\end{array}$ & $\begin{array}{l}\text { Mild to moderate; often loss of distal tip } \\
\text { of extremity }\end{array}$ \\
\hline $\begin{array}{l}\text { 4th degree } \\
\text { Skin, subcutaneous tissue, muscle, tendon } \\
\text { and bone freezing; little oedema but deeply } \\
\text { red/purple tissue becoming black and mummified }\end{array}$ & $\begin{array}{l}\text { Grade } 4 \\
\text { Cyanosis extends to carpal/tarsal bones } \\
\text { after thawing }\end{array}$ & $\begin{array}{l}\text { Amputation commonly required, with } \\
\text { functional sequelae }\end{array}$ \\
\hline
\end{tabular}


painful and adequate analgesia must be given. Adequate rewarming time varies from 30 to 60 minutes, but can be judged clinically by palpation of pliable tissue and appearance of a red or purple colour. Once thawed, the degree and grading of the injury can be established. Documentation using photographs is recommended, following which loose protective dressings can be applied. Some centres recommend the use of topical aloe vera gel for its antiprostaglandin effect, and simple antibiotic and tetanus prophylaxis.

Early surgical intervention is not advocated unless there is unambiguous evidence of compartment syndrome after thawing. This occurs rarely. Surgeons used to seeing gangrene from peripheral vascular disease, but who have little or infrequent exposure to frostbite cases, may not anticipate the degree to which frostbite injuries can be salvaged. Certainly, surgery should not be undertaken in the absence of obvious sepsis without first performing imaging of the affected area. In this respect, either digital subtraction angiography or technetium-99 bone scanning have been shown to provide the best prognostic information. ${ }^{[20,21]}$ More recently, magnetic resonance angiography, which may be more widely available in SA, has been used as an alternative. Early angiography, however, does offer the option of performing intra-arterial thrombolysis (discussed below).

Deep frostbite injuries will normally demarcate clearly with dry necrosis of the devitalised tissue, allowing amputation at $6-12$ weeks post injury. There is a strong association between frostbite injuries requiring amputation and chronic regional pain. Analgesia before and after amputation should therefore be optimal and early referral to a pain specialist is warranted if the patient's pain is not well controlled.

\section{Emerging therapies for cold injuries}

The increasing use of extracorporeal life support and/or extracorporeal membrane oxygenation (ECMO) worldwide has led to recognition of its value in providing rapid central rewarming to patients with severe hypothermia. Although ECMO is still rare in SA, any hospital that provides cardiopulmonary bypass services for cardiothoracic surgery has the capability to rewarm patients in this fashion. Suitable cases - particularly those in which profound cooling occurred before apparent cardiorespiratory arrest - should be considered for early involvement of teams (typically cardiac surgeons and perfusionists) if this is to be attempted. In some settings, recovery to normal neurological function has been achieved after profound hypothermia. Indeed, full recovery has been recorded after accidental hypothermia with a core temperature of $13.7^{\circ} \mathrm{C}$ using this approach. ${ }^{[22]}$

Many novel approaches have been attempted for management of frostbite, including hyperbaric oxygen therapy, alpha-adrenergic and calcium channel blockers, phosphodiesterase inhibitors, systemic heparinisation and topical therapies. Of these, the most promising interventions that have entered routine practice are the use of intra-arterial thrombolysis, and intravenous prostacyclin analogue infusions. ${ }^{[23-25]}$ Several studies have shown that initiation of thrombolysis with recombinant tissue plasminogen activator and/or iloprost infusion commenced within 24 hours of rewarming significantly decreases the degree of tissue loss due to frostbite. ${ }^{[26,27]}$ Iloprost carries the advantage of not requiring facilities for angiography, but the intravenous version of the drug is not widely available; this indication is considered off-label. Some work suggests that thrombolysis may not add to therapy where iloprost is available, but it is still used for severe cases and where iloprost cannot be obtained. ${ }^{[26]}$ While this is achievable in an African setting, it should only be attempted in units with experience in endovascular thrombolysis, where adequate monitoring is available and contraindications have been excluded. ${ }^{[24]}$

\section{Scenario resolution}

High in the Drakensberg, you recognise that your impromptu patient may well have frostbite, but the greatest danger comes from his obvious moderate to severe hypothermia. Concerned by his confusion and inability to stand, you have the group carry him to one of the cabins while a member of the party calls for an ambulance. Removing his wet clothing, shoes and rings, you wrap him in blankets warmed at the fire. With assistance he can sip warm, sweet tea. You accompany him to the hospital, where his core temperature is recorded at $33.5^{\circ} \mathrm{C}$ on arrival, and warming is continued using a forced-air warmer, and his feet are thawed in water baths at $40^{\circ} \mathrm{C}$. Seeing evidence of at least grade 3 frostbite of his toes, you are able to discourage the local surgeon from aggressive debridement, rather recommending transfer to a referral centre. You later hear that he underwent angiography and thrombolysis, which prevented significant tissue loss.

1. South African Weather Service. What are the temperature, rainfall and wind extremes in SA? 2017. http://www.weathersa.co.za/learning/climate-questions/39-what-are-the-temperature-rainfall-andwind-extremes-in-sa (accessed 2 April 2017)

2. Baumgartner EA, Belson M, Rubin C, Patel M. Hypothermia and other cold-related morbidity emergency department visits: United States, 1995 - 2004. Wilderness Environ Med 2008;19(4):233237. http://dx.doi.org/10.1580/07-WEME-OR-104.1

3. Lapostolle F, Couvreur J, Koch FX, et al. Hypothermia in trauma victims at first arrival of ambulance personnel: An observational study with assessment of risk factors. Scand J Trauma Resusc Emerg Med
pestims personnel: An observational study with assessment of risk factors.
2017;25(1):43. http://dx.doi.org/10.1186/s13049-017-0349-1

4. Lapostolle F, Sebbah JL, Couvreur J, et al. Risk factors for onset of hypothermia in trauma victims: The Lapostolle F, Sebbah JL, Couvreur J, et al. Risk factors for onset of hypothermia in t
HypoTraum study. Crit Care 2012;16(4):R142. http://dx.doi.org/10.1186/cc11449

5. Ireland S, Endacott R, Cameron P, Fitzgerald M, Paul E. The incidence and significance of accidental hypothermia in major trauma - a prospective observational study. Resuscitation 2011;82(3):300-306. http://dx.doi.org/10.1016/j.resuscitation.2010.10.016

6. Waibel BH, Schlitzkus LL, Newell MA, Durham CA, Sagraves SG, Rotondo MF. Impact of hypothermia (below 36 degrees C) in the rural trauma patient. J Am Coll Surg 2009;209(5):580-588. http://dx.doi org/10.1016/j.jamcollsurg.2009.07.021

7. Hardcastle TC, Stander M, Kalafatis N, Hodgson RE, Gopalan D. External patient temperature control in emergency centres, trauma centres, intensive care units and operating theatres: A multi-society literature review. S Afr Med J 2013;103(9):609-611. http://dx.doi.org/10.7196/samj.7327

8. Ahmad Z. Managing frostbite in a South African patient. Int Wound J 2013;10(4):480-481. http:// dx.doi.org/10.1111/j.1742-481X.2012.00946.x

9. Zafren K, Giesbrecht GG, Danzl DF, et al. Wilderness Medical Society practice guidelines for the Zafren K, Giesbrecht GG, Danzl DF, et al. Wilderness Medical Society practice guidelines for the
out-of-hospital evaluation and treatment of accidental hypothermia. Wilderness Environ Med out-of-hospital evaluation and treatment of accidental hypoth
2014; 25(4):425-445. http://dx.doi.org/10.1016/j.wem.2014.09.002

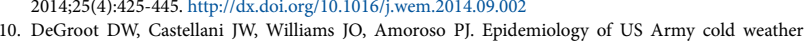
DeGroot DW, Castellani JW, Williams JO, Amoroso PJ. Epidemion
injuries, 1980 - 1999. Aviat Space Environ Med 2003;74(5):564-570.

11. Burgess JE, Macfarlane F. Retrospective analysis of the ethnic origins of male British army soldiers with peripheral cold weather injury. J R Army Med Corps 2009;155(1):11-15.

12. Maley MJ, Eglin CM, House JR, Tipton MJ. The effect of ethnicity on the vascular responses to cold exposure of the extremities. Eur J Appl Physiol 2014;114(11):2369-2379. http://dx.doi.org/10.1007/ s00421-014-2962-2

13. Durrer B, Brugger H,Syme D, Tipton MJ.The medical on-site treatment of hypothermia:ICAR-MEDCOM recommendation. High Alt Med Biol 2003;4(1):99-103. http://dx.doi.org/10.1089/152702903321489031

14. McIntosh SE, Opacic M, Freer L, et al. Wilderness Medical Society practice guidelines for the prevention and treatment of frostbite: 2014 update. Wilderness Environ Med 2014;25(Suppl 4):S43-S54. http:// dx.doi.org/10.1016/j.wem.2014.09.001

15. Soar J, Perkins GD, Abbas G, et al. European Resuscitation Council Guidelines for Resuscitation 2010. Soar Jion 8. Cardiac arrest in special circumstances: Electrolyte abnormalities, poisoning, drowning
Section Section 8. Cardiac arrest in special circumstances: Electrolyte abnormalities, poisoning, drowning,
accidental hypothermia, hyperthermia, asthma, anaphylaxis, cardiac surgery, trauma, pregnancy accidental hypothermia, hyperthermia, asthma, anaphylaxis, cardiac surgery, trauma, pregnancy,
electrocution. Resuscitation 2010;81(10):1400-1433. http://dx.doi.org/10.1016/i.resuscitation.2010.08.015

16. Dectrocution. Resuscitation 2010;81(10):1400-1433. http:///x.doi.org/10.1016/j.resuscitation.2010.08.015
I Johnson C, Johnson C, Oakley H, Roberts B. Cold climates. In: Imray C, ed. Oxford Handbook Davis I, Johnson C, Johnson C, Oakley H, Roberts B. Cold climates. In: Imray C, ed. Oxford
of Expedition and Wilderness Medicine. Oxford: Oxford University Press, 2015:607-636.

17. Strapazzon G, Procter E, Paal P, Brugger H. Pre-hospital core temperature measurement in accidental and therapeutic hypothermia. High Alt Med Biol 2014;15(2):104-111. http://dx.doi.org/10.1089/ ham. 2014.1008

18. Mills WJ Jr. Summary of treatment of the cold injured patient. Frostbite. Alaska Med 1983;25(2):33-38 9. Cauchy E, Chetaille E, Marchand V, Marsigny B. Retrospective study of 70 cases of severe frostbite lesions: A proposed new classification scheme. Wilderness Environ Med 2001;12(4):248-255.

20. Cauchy E, Chetaille E, Lefevre M, Kerelou E, Marsigny B. The role of bone scanning in severe frostbite of the extremities: A retrospective study of 88 cases. Eur J Nucl Med 2000;27(5):497-502.

21. Cauchy E, Marsigny B, Allamel G, Verhellen R, Chetaille E. The value of technetium 99 scintigraphy in the prognosis of amputation in severe frostbite injuries of the extremities: A retrospective study of 92 severe frostbite injuries. J Hand Surg Am 2000;25(5):969-978.

22. Gilbert M, Busund R, Skagseth A, Nilsen PA, Solbø JP. Resuscitation from accidental hypothermia of 13.7 degrees $C$ with circulatory arrest. Lancet 2000;355(9201):375-376. http://dx.doi.org/10.1016 S0140-6736(00)01021-7

23. Hallam MJ, Cubison T, Dheansa B, Imray C. Managing frostbite. BMJ 2010;341:c5864. http://dx.doi. org/10.1136/bmj.c5864

24. Handford C, Buxton P, Russell K, et al. Frostbite: A practical approach to hospital management. Extrem Physiol Med 2014;3:7. http://dx.doi.org/10.1186/2046-7648-3-7

25. Handford C, Thomas O, Imray CHE. Frostbite. Emerg Med Clin North Am 2017;35(2):281-299. http:// dx.doi.org/10.1016/j.emc.2016.12.006

26. Cauchy E, Cheguillaume B, Chetaille E. A controlled trial of a prostacyclin and rt-PA in the treatment of severe frostbite. N Engl J Med 2011;364(2):189-190. http://dx.doi.org/10.1056/NEJMc1000538

27. Cauchy E, Davis CB, Pasquier M, et al. A new proposal for management of severe frostbite in the austere environment. Wilderness Environ Med 2016;27(1):92-99. http://dx.doi.org/10.1016/j. wem.2015.11.014 